\title{
Evaluation of the Possibility to Obtain Nanostructured Bainite in High-Carbon and High-Silicon 9XC Bearing Steel
}

\author{
Dominika Baran and Aleksandra Królicka iD
}

\author{
(Submitted March 30, 2020; in revised form June 18, 2020; published online August 17, 2020)
}

\begin{abstract}
The main aim of this research is the evaluation of the possibility of obtaining a nanostructured bainite after isothermal heat treatment of 9XC (according to GOST standard) bearing steel. It was found that the annealing at low temperature $\left(250{ }^{\circ} \mathrm{C}\right)$ allows to obtain the microstructure of nanobainite consisting of nanometric-scale bainitic ferrite laths and austenite with a dominant film-like morphology. In the case of higher isothermal treatment temperature $\left(300{ }^{\circ} \mathrm{C}\right)$, a microstructure was slightly coarser and the proportion of austenite with blocky morphology increased. The identification of a highly refined microstructure was performed using TEM and SAED methods. Besides, isothermal annealing temperature significantly affects hardness. The hardness difference between annealing at $250{ }^{\circ} \mathrm{C}(630.0 \pm 4.4 \mathrm{HV1})$ and $300^{\circ} \mathrm{C}$ $(517.3 \pm 1.1 \mathrm{HV1})$ was over $100 \mathrm{HV}$. Such a substantial decrease in hardness was caused by the fraction and morphology of the occurred phases. Due to the high silicon content in the tested steel $(1.54 \%)$, the carbide precipitation was delayed, but locally the cementite precipitates were confirmed. Based on the research, it was found that the commercial 9XC steel is appropriate for nanostructurization in the low ranges of bainitic transformation. Designing of further heat treatment should be focused on the lowest possible temperature of isothermal annealing (even below $250{ }^{\circ} \mathrm{C}$ ).
\end{abstract}

Keywords 9XC steel, bainite transformation, bearing steels, nanobainite, Si-rich steels, TEM study

\section{Introduction}

Bhadeshia and Edmonds (Ref 1) were the first to introduce methods for designing steels with high mechanical properties that are characterized by a microstructure consisting of nanometric-scale bainitic ferrite laths and austenite with filmlike morphology. To obtain nanostructured bainite (NB), the heat treatment included low-temperature long-term annealing is performed (Ref 2-6). The chemical composition of steel is also an important factor in designing nanobainitic steel. Elements such as carbon, silicon and manganese significantly enhance the austenite mechanical stability (Ref 7). Sufficient amount of $\mathrm{Si}$ (more than $1.5 \mathrm{wt} . \%$ ) retards the precipitation of carbides into bainite plates (Ref 4, 8-10). The nanobainitic steels exhibit high tensile strength (over $2000 \mathrm{MPa}$ ), ductility (up to $14 \%$ ) and fracture toughness (40 MPa $m^{1 / 2}$ ) (Ref 3, 9, 11-13). Besides, steel after isothermal heat treatment is less prone to quench cracking and generation of undesirable tensile residual stresses at the surface (Ref 10,13). Due to the high mechanical properties, NB steels are widely used in industrial areas and applied in roller bearings (Ref 2,11,14), ballistic shields (Ref $15)$ and railways (Ref 12, 14). Moreover, in 2009 one of the

Dominika Baran and Aleksandra Królicka, Faculty of Mechanical Engineering, Wrocław University of Science and Technology, Wybrzeże Wyspiańskiego 27, 50-370 Wrocław, Poland. Contact e-mail: aleksandra.krolicka@pwr.edu.pl. largest rolling bearing companies established a technical center in cooperation with Cambridge University where the nanostructured bainite discoverer works (Ref 11). This fact and numerous researches demonstrate a step toward the industrialization of these microstructures (Ref 16).

In the last few years, research of nanostructured bainite in bearing steels has developed significantly. Zhang et al. (Ref 17) developed a method of producing a NB structure in the surface layer of carburized steel. Hereby, higher wear resistance and a higher fatigue life for rolling contact were obtained (Ref 18). Due to these properties, this technique is suitable for the production of the bearing (Ref 6,11$)$. However, the vast majority of research still concerns only specially designed chemical compositions (Ref 10, 19, 20), and only a small amount of commercially available bearing steels (Ref 4, 13, 21, 22). The present paper aims to study the microstructure and of 9XC grade (according to GOST standard) bearing steel subjected to two different isothermal heat treatments, to examine the possibility of obtaining a nanostructured bainite. The obtaining of NB with high mechanical properties in commercially available bearing steel makes the possibility to easier use this material for industrial production. The chemical compositions of the other bearing steels with a microstructure of nanostructured bainite were compared as given in Table 1 with the studied bearing 9XC steel.

In this work was analyzed low-temperature isothermal heat treatment aimed at achieving high properties that are important for bearing steels (hardness, abrasive resistance, contact fatigue). Maximization of these mechanical properties can be achieved by low-temperature bainitic transformation and microstructure consisting of nanometric-scale baintic ferrite laths and austenite with dominant film-like morphology (Ref 12, 23-25). For this reason, an isothermal heat treatment was designed in the temperature range of $250-300{ }^{\circ} \mathrm{C}$. 
Table 1 Chemical composition of nanostructured bainite bearing steels (NBBS) and tested 9XC bearing steel

\begin{tabular}{|c|c|c|c|c|c|c|c|c|c|}
\hline \multirow[b]{2}{*}{ No. } & \multirow[b]{2}{*}{ Prod. } & \multicolumn{7}{|c|}{ Weight content, \% } & \multirow[b]{2}{*}{ References } \\
\hline & & $\mathbf{C}$ & $\mathbf{S i}$ & Mn & $\mathrm{Cr}$ & Mo & Al & $\mathbf{N i}$ & \\
\hline 1 & Ind. & 0.94 & 1.54 & 0.44 & 1.05 & 0.01 & 0.02 & 0.18 & This research \\
\hline 2 & Lab. & 0.99 & 0.83 & 0.24 & 1.54 & 0.35 & 0.97 & $\ldots$ & Ref 6 \\
\hline 3 & Lab. & 1.05 & 1.20 & 0.26 & 1.50 & 0.38 & 0.04 & $\ldots$ & Ref 10 \\
\hline 4 & Lab. & 1.05 & 1.51 & 0.26 & 1.54 & 0.35 & 0.03 & $\ldots$ & Ref 10 \\
\hline 5 & Lab. & 1.15 & 0.58 & 0.21 & 1.42 & $\ldots$ & 0.65 & $\ldots$ & Ref 6 \\
\hline 6 & Lab. & 1.26 & 0.49 & 0.49 & 1.56 & $\ldots$ & 1.37 & $\ldots$ & Ref 20 \\
\hline 7 & Ind. & $0.93-1.05$ & $0.45-0.75$ & $1.00-1.20$ & $1.40-1.65$ & $\leq 0.1$ & $\ldots$ & $\ldots$ & Ref 22 \\
\hline 8 & Ind. & 0.94 & 0.24 & 0.31 & 1.38 & 0.04 & $\ldots$ & 0.13 & Ref 50 \\
\hline 9 & Ind. & 0.97 & 0.24 & 0.64 & 1.75 & 0.26 & $\ldots$ & $\ldots$ & Ref 4 \\
\hline 10 & Ind. & 0.98 & 0.29 & 0.29 & 1.78 & 0.16 & $\ldots$ & $\ldots$ & Ref 4 \\
\hline 11 & Ind. & 0.96 & 0.60 & 1.18 & 1.48 & 0.03 & $\ldots$ & $\ldots$ & $\operatorname{Ref} 4,50$ \\
\hline 12 & Ind. & 0.97 & 0.28 & 0.28 & 1.38 & 0.06 & 0.04 & $\ldots$ & Ref 21 \\
\hline 13 & Ind. & 1.00 & 1.25 & 0.96 & 1.39 & 0.03 & $\ldots$ & 0.12 & Ref 13,50 \\
\hline
\end{tabular}

Bold indicates which results have been obtained in the current research ind. industrial material, lab. laboratory-prepared material

Table 2 The chemical composition of tested 9XC bearing steel

\begin{tabular}{lcccccccccc}
\hline \multicolumn{10}{c}{ Weight content, \% } \\
\hline $\mathbf{C}$ & $\mathbf{S i}$ & $\mathbf{M n}$ & $\mathbf{C r}$ & $\mathbf{M o}$ & $\mathbf{A l}$ & $\mathbf{N i}$ & $\mathbf{P}$ & $\mathbf{S}$ & $\mathbf{V}$ \\
\hline 0.94 & 1.54 & 0.44 & 1.05 & 0.01 & 0.022 & 0.18 & 0.01 & 0.007 & 0.006 \\
\hline
\end{tabular}

\section{Materials and Methods}

\subsection{Materials}

The 9XC grade (according to GOST standard) bearing steel was subjected to an isothermal heat treatment to obtain a nanostructured bainite (8-mm-thick sheet). The tested steel contains a high content of carbon (0.94 wt.\%) and silicon (1.54 wt.\%) and does not contain a significant content of carbide-forming additives such as V, W and Mo (Table 2). The steel in the as-delivered state had a typical structure for softening annealing, spheroidal cementite in the ferrite matrix. However, it was found that it was incomplete spheroidization, because the cementite morphology was not only spheroidal but also lamellar (Fig. 1). Furthermore, the dimensions of the cementite particles exhibit various dimensions. The input structure in the context of heat treatment is important due to the requirement obtained homogeneous austenite. The stability of plate-like cementite is generally lower than the spheroidal structure, which requires a longer austenitization time. Besides the morphology of cementite, it was reported that higher content of silicon retarded reverse transformation kinetics (Ref 26). For this reason, an enough long austenitization time was planned. The measured hardness of the steel in the as-delivered state was $243.0 \pm 2.3 \mathrm{HV} 1$.

The martensite start $\left(\mathrm{M}_{\mathrm{s}}\right)$ and bainite start $\left(\mathrm{B}_{\mathrm{s}}\right)$ temperatures were calculated by different empirical equations (Table 3 ). The differences in results are caused by the use of various relationships in which some alloying additives are included. Moreover, they rarely contain the influence of grain size and austenitization conditions. The obtained results were used to estimate the actual Ms and Bs temperatures, which play a key role in heat treatment design.

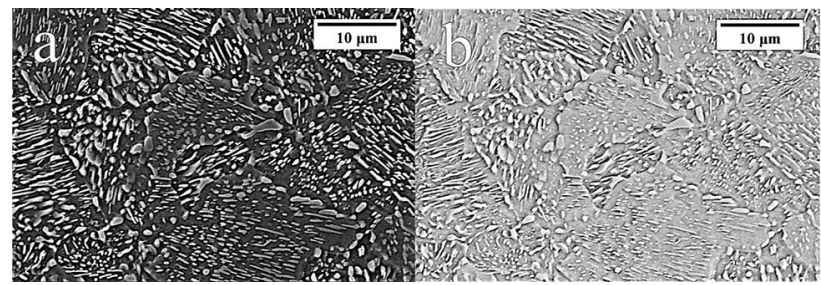

Fig. 1 The microstructure of the 9XC steel in as-delivery state. Spheroidal and partially lamellar cementite in the ferrite matrix. SEM (a) SE detector (b) BSE detector

Cuboidal samples with dimensions of $8 \times 10 \times 20 \mathrm{~mm}$ were intended for heat treatment processes. Isothermal annealing was carried out at temperatures of 250 and $300{ }^{\circ} \mathrm{C}$ (Table 4), which, based on calculations, are in the range of bainitic transformation. Different isothermal treatment times $\left(120 \mathrm{~h}\right.$ for $250{ }^{\circ} \mathrm{C}$ and $72 \mathrm{~h}$ for $300{ }^{\circ} \mathrm{C}$ ) have also been used because at lower temperatures, bainitic transformation requires a longer time (Ref 3 ). The austenitization of both samples was carried out at $950{ }^{\circ} \mathrm{C}$ for $30 \mathrm{~min}$. The samples were then immediately transferred to furnace with liquid tin at the isothermal annealing temperature. After isothermal heating, the samples were cooled in water to ambient temperature.

\subsection{Methods}

Microscope observations were carried out using an optical microscope Eclipse MA200 with a CCD Nikon DS-fi camera. The microstructure of the samples was examined using a Jeol JSM-6610A scanning electron microscope (SEM) in topographic (SE detector) and material (BSE detector) contrast. The 
Table 3 The martensite start $\left(M_{\mathrm{s}}\right)$ and bainite start $\left(B_{\mathrm{s}}\right)$ temperatures calculated by empirical equations for the 9XC bearing steel

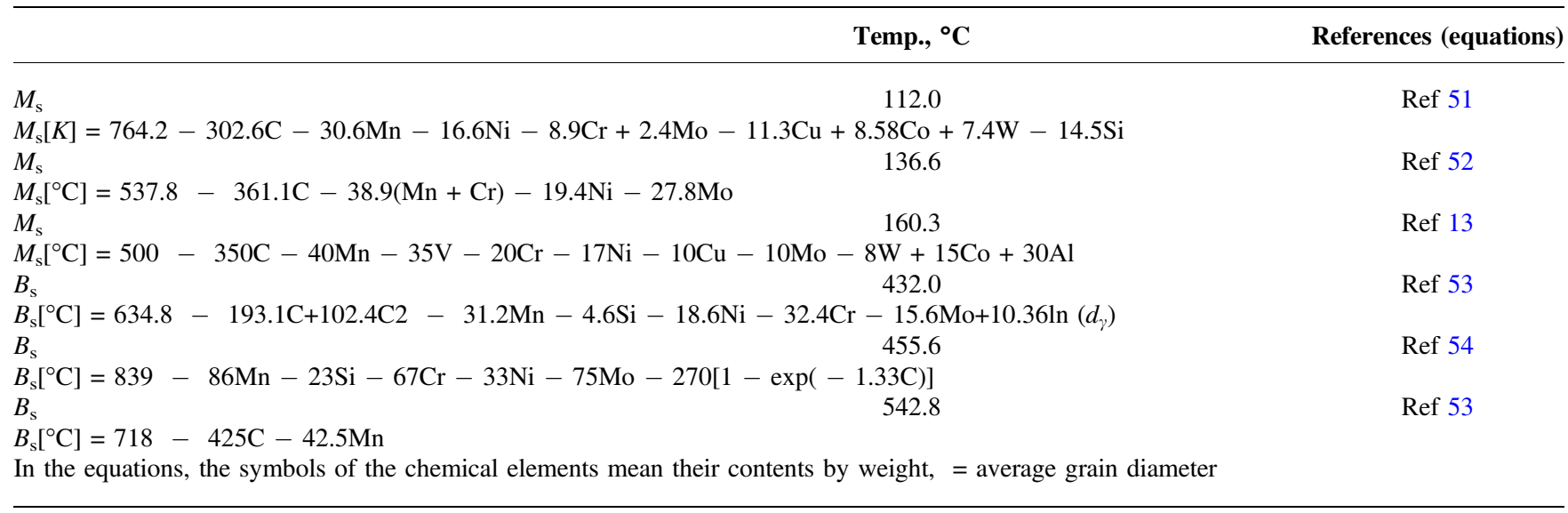

Table 4 The heat treatment parameters of the 9XC bearing steel

\begin{tabular}{lcccr}
\hline Designation & $\boldsymbol{T}_{\text {aust }},{ }^{\circ} \mathrm{C}$ & $\boldsymbol{t}_{\text {aust }}, \boldsymbol{m i n}$ & $\boldsymbol{T}_{\text {iso }},{ }^{\circ} \mathrm{C}$ & $\boldsymbol{t}_{\text {iso }}, \mathbf{h}$ \\
\hline B-250-120 & 950 & 30 & 250 & 120 \\
B-300-72 & 950 & 30 & 300 & 72 \\
\hline
\end{tabular}

microstructures were also observed using a HITACHI H-800 transmission electron microscope (TEM). Sample preparation for TEM observations included grinding of pre-cut $1.2-\mathrm{mm}$ plates to a thickness of about $100 \mu \mathrm{m}$, cutting disks with a diameter of $3 \mathrm{~mm}$ using an electro-erosion method. In the next stage, electrolytic polishing on a Struers TenuPol device and ionic polishing were performed on a GATAN DuoMill. The hardness of the samples after isothermal heat treatment was determined by the Vickers method on a MMT-X3 hardness tester. A load of $9.807 \mathrm{~N}$ was applied for $15 \mathrm{~s}$. Five measurements were taken in the centerline of the samples under consistent conditions with the ASTM E92 standard. The Vickers hardness results were estimated to the HRC scale based on charts (ASTM E40 Hardness Conversion Tables of Metals). A 95\% confidence interval was determined to relate hardness measurements to the expected value ( $t$-distribution).

Cuboidal specimens $8 \times 10 \times 20 \mathrm{~mm}$ were prepared for grain growth investigations. The $9 \mathrm{XC}$ grade steel was austenitized at $950{ }^{\circ} \mathrm{C}$ for $30 \mathrm{~min}$, and then the sample was water-cooled. Because silicon delays the precipitation of cementite (Ref $27-$ 29), the sample was tempered at $550{ }^{\circ} \mathrm{C}$ for $1 \mathrm{~h}$ to allow the prior austenite grains to be revealed (Ref 30). Metallographic samples were made on the cross section by grinding with abrasive papers and polishing with diamond paste. The prepared sample was etched with a saturated $5 \%$ picric acid solution at $60{ }^{\circ} \mathrm{C}$. The grain size determination method was dictated by ensuring objective measurement by randomness. After verifying that the entire sample exhibits homogeneous grains of prior austenite (PAG), five areas were randomly selected $(500 \times$ magnification $)$. Then, 20 grains were randomly selected from each micrograph for measurements. Grains
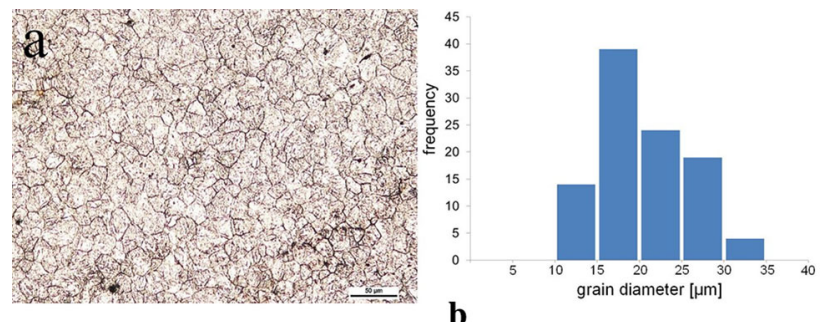

Fig. 2 (a) Revealed prior austenite grains of 9XC grade steel after austenitization at $950{ }^{\circ} \mathrm{C}$ for $30 \mathrm{~min}$. Etched by saturated picric acid solution, light microscopy. (b) Histogram of the average grain diameter

diameter was determined by measuring two diagonals of grain (the diameter of a single grain was the average of both diagonals) using ImageJ software.

\section{Results}

Prior austenite grain size impacts the mechanical properties of nanobainite (NB) (Ref 31) by direct influence on the kinetics of transformation (Ref 32) and hence the resulting microstructure (Ref 30, 33). Revealed prior austenite grains after austenitization in tested temperature exhibited stable growth, and no abnormal grains were found (Fig. 2). The histogram of the grain size was characterized by a normal distribution (Fig. 2b). Due to the higher tolerance to outliers, the median better represents the actual grain size than the average value. For this reason, both mean, standard deviation and the median were compared (Table 5). In simplified terms, the $\frac{1}{2}$ interquartile range value was considered to be a spread. Thus, it was determined that the grain diameter for the austenitization tested conditions was $14.5 \pm 4.1 \mu \mathrm{m}$. The obtained result indicates that at $950{ }^{\circ} \mathrm{C}$ the prior austenite grain boundaries are stable and do not exhibit any anomalies. The average grain diameter corresponds approximately to No. 9 according to ASM 112.

The results of hardness measurements are presented in Table 6. For sample B-250-120, the hardness was $630.0 \pm 4.4$ HV1, which can be estimated to 57 HRC. In contrast, sample 
Table 5 Grain size measurement results of the $9 \mathrm{XC}$ grade steel after austenitization at $950{ }^{\circ} \mathrm{C}$ for 30 min

\begin{tabular}{lcccccc}
\hline Material & Mean of grain diameter, $\boldsymbol{\mu m}$ & $\boldsymbol{\sigma}$ & Median from grain diameter, $\boldsymbol{\mu m}$ & $\mathbf{Q 1}$ & $\mathbf{Q 3}$ & $\mathbf{I Q R}$ \\
\hline 9XC grade steel & 15.6 & \pm 5.6 & 14.5 & 11.4 & 19.6 & 8.2 \\
\hline
\end{tabular}

Table 6 The measured hardness of 9XC steel after isothermal heat treatment

\begin{tabular}{lcccc}
\hline Sample & Measured hardness [HV1] & SE & 95\% confidence interval & Calculated hardness [HRC] \\
\hline B-250-120 & 630.0 & 4.4 & {$[617.8 ; 642.2]$} & 57 \\
B-300-72 & 517.3 & 1.1 & {$[514.2 ; 520.5]$} & 50 \\
\hline
\end{tabular}

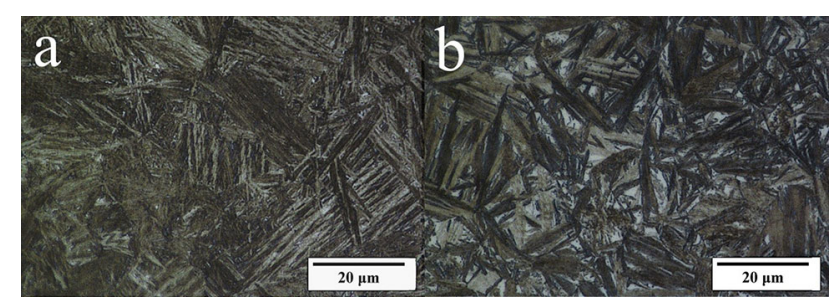

Fig. 3 The microstructures of 9XC steel after isothermal heat treatment. (a) (B-250-120) Visible bainitic ferrite packets, (b) (B300-72) bainitic ferrite packets and blocky retained austenite. Etched by nital, light microscopy

B-300-72 had a much lower level of hardness, which was $517.3 \pm 1.1 \mathrm{HV} 1$ (approximately $50 \mathrm{HRC}$ ). It was also found that the average value of B-250-120 sample with $95 \%$ confidence is within the range of $[617.8 ; 642.2]$, while B$300-72$ sample in the range of $[514.2 ; 520.5]$. Thus, the difference between the samples is significant and exceeds 100 HV. To explain the difference in hardness, a detailed microstructure analysis was carried out in the following sections.

The microstructure of both samples consists of bainitic ferrite laths and retained austenite. The bainitic ferrite packets exhibited different orientations in the area of prior austenite grains (Fig. 3). The width of the bainitic ferrite packets was smaller for the B-250-1200 sample (Fig. 3a) compared to the B-300-72 sample (Fig. 3b). However, it should be highlighted that this does not allow to determine the width of the bainitic ferrite laths, which are located in the single packet. A clear difference was found in the content of austenite with blocky morphology. Based on the light microscopy photomicrographs of the B-250-120 sample, it was determined that austenite with blocky morphology did not occur (Fig. 3a). On the other hand, for the B-300-72 sample, the content of blocky austenite is relatively high, and the dimensions of the austenite islands are relatively large (Fig. 3b). Due to the nanometric scale of austenite with film-like morphology, its presence cannot be determined based on light microscopy.

Identification using the SEM method allowed the revealing of ferrite lath morphology inside bainite packets (Fig. 4). It was found that for both samples, refined bainitic ferrite laths occurred in the area of the packets. On the other hand, this method also does not allow the assessment of the microstructure refinement, because the dimensions of austenite with film-

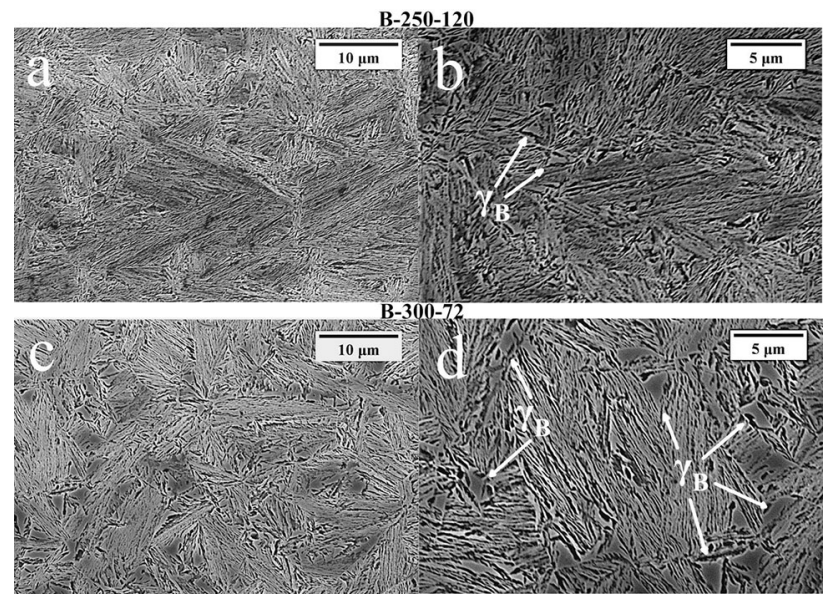

Fig. 4 SEM micrographs of the 9XC steel after isothermal heat treatment: (a) bainitic ferrite packets. The visible various orientations of bainite packets inside the prior austenite grains. (b) (B-250-120) Visible bainitic ferrite laths inside bainite packets and low content of blocky austenite $\left(\gamma_{\mathrm{B}}\right)$. (c) (B-300-72) Bainitic ferrite packets and blocky austenite. The visible various orientations of bainite packets inside the prior austenite grains. (d) Visible bainitic ferrite laths inside bainite packets and high content of blocky austenite $\left(\gamma_{\mathrm{B}}\right)$. Etched by nital, scanning electron microscopy

like morphology may exceed the resolution limit of the used scanning electron microscope. A significant difference was also found in the term of content and size of blocky austenite. In the case of the B-250-120 sample, locally blocky austenite occurred and was characterized by small dimensions (Fig. 4b). On the other hand, the identified blocky austenite in case of the B-300-72 sample was found in a higher content and formed islands of relatively large dimensions (usually about 1-3 $\mu \mathrm{m}$ ) (Fig. 4d).

The TEM investigations and the SAED method were used to assess the microstructure refinement and identification of austenite with film-like morphology. The microstructure of both samples consisted of bainitic ferrite laths and film-like austenite (Fig. 5). The austenite with film-like morphology was distributed between the bainitic ferrite laths. To estimate the refinement of bainitic ferrite laths and film-like austenite, bright-field image photomicrographs were selected and the widths of laths were measured. Representative TEM photomicrographs are shown in Fig. 6. It was found that the B-250-120 


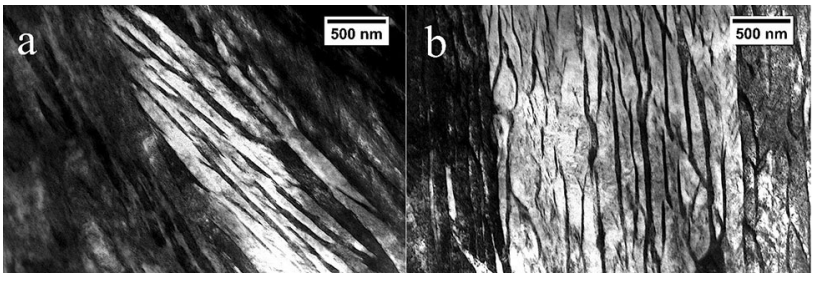

Fig. 5 Bright-field images of 9XC steel after isothermal heat treatments. (a) Sample B-250-120. Bainitic ferrite laths and film-like austenite. (b) Sample B-300-72. Bainitic ferrite laths and film-like retained austenite. $150 \mathrm{kV}$, TEM

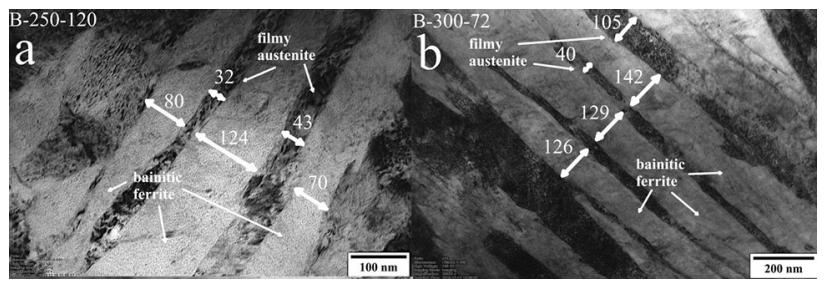

Fig. 6 Representative bright-field images of 9XC steel after isothermal heat treatment used to assess microstructure refinement (a) B-250-120 sample. (b) B-300-72 samples. $150 \mathrm{kV}$, TEM

sample was characterized by smaller dimensions of microstructure components. The width of bainitic ferrite laths mainly was in the range of $60-130 \mathrm{~nm}$, while the width of film-like austenite was in the range of 30-40 $\mathrm{nm}$. It can be stated that the obtained microstructure generally meets the requirements for nanostructure (dimensions below $100 \mathrm{~nm}$ ). The presence of bainitic ferrite laths with a width exceeding $100 \mathrm{~nm}$ was also identified, but laths with lower widths (below $100 \mathrm{~nm}$ ) predominated. However, the B-300-72 sample was characterized by the coarser microstructure components. The width of bainitic ferrite laths was in the range of $120-150 \mathrm{~nm}$, and in the range of 30-110 nm for film-like austenite. Thus, the temperature of the isothermal heat treatment affected the width of the bainitic ferrite laths as well as the austenite with film-like morphology.

Crystallographic orientations between ferrite and austenite in steels are described by four main relationships (OR): Bain OR (Ref 34), Kurdjumov-Sachs (K-S) OR (Ref 35), Greninger-Troiano (G-T) OR (Ref 36) and Nishiyama-Wassermann (N-W) OR (Ref 37). The most common crystalline orientation relationships (OR) between the face-centered cubic (fcc) and body-centered cubic (bcc) structures are by NishiyamaWassermann (N-W) and Kurdjumov-Sachs (K-S) (Ref 38). In nanobainitic steel, the orientations between bainitic ferrite and retained austenite are similar to that between the N-W and K-S orientations, which is confirmed in Ref 39. There is an assumption that the close-packed plane $\{110\}$ of the bainitic ferrite is parallel to the $\{111\}$ plane of the austenite, meaning that propagation of the bainite sheaves has specific orientations with the parent phase (austenite) (Ref 40). There are 24 variants in the K-S relationship and 12 variants in the $\mathrm{N}-\mathrm{W}$ relationship between bainitic ferrite and austenite (Ref 41, 42). It was found that the orientation between bainitic ferrite and austenite in the case of B-250-120 sample was approximately consistent with $\mathrm{N}-\mathrm{W} \quad$ OR: $\quad[0 \overline{1} 1]_{\alpha} \|[\overline{1} \overline{1} 2]_{\gamma}$, and $(011)_{\alpha} \|(111)_{\gamma}$-variant V3 (Fig. 7c) and in the case of the B-300-72 sample was

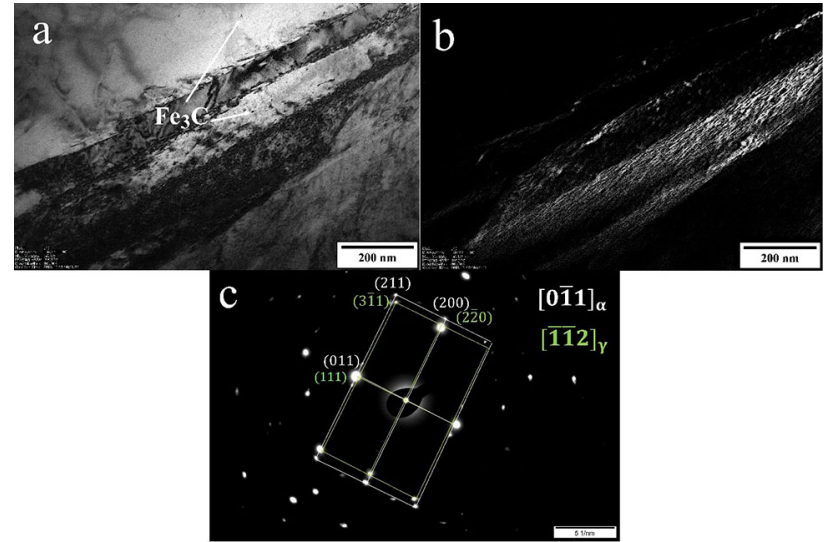

Fig. 7 (a) Bright-field image of the B-250-120 sample. (b) Dark field image obtained from reflection (111) from austenite (Fig. 7c). (c) Selected area diffraction pattern (SAED) of areas shown in Fig. 7a, along with the solution: $[0 \overline{1} 1]_{\alpha} \|[\overline{1} \overline{1} 2]_{\gamma} .150 \mathrm{kV}$, TEM

approximately consistent with K-S OR: $[01 \overline{1}]_{\gamma} \|[\overline{1} 1 \overline{1}]_{\alpha}$ and $(111)_{\gamma} \|(110)_{\alpha}-$ variantV4 (Fig. 8c). Therefore, the obtained microstructures consisted of ferrite and austenite films, which confirms the received of the nanostructured bainite. Besides, cementite precipitations inside bainitic ferrite with nanometric dimensions were locally found for both samples (Fig. 7a and 8a). Thus, the amount of silicon in 9XC steel was sufficient to retard the cementite precipitation from austenite and limited the cementite precipitation from the bainitic ferrite.

\section{Discussion}

Silicon retards the carbide precipitation in the process during the isothermal annealing and hereby increases carbon content in retained austenite, which enhances the austenite stability. According to Zhao et al. (Ref 10), high Si content leads to the increase in retained austenite fraction and causes a carbidefree bainitic microstructure in annealed samples. In the tested 9XC steel with $1.54 \%$ Si content, nanostructured bainite with limited content of cementite was obtained, which confirms the impact of silicon content on the microstructure morphology.

The relatively fine prior austenite grains were obtained (median form grain diameter: $14.5 \pm 4.1 \mu \mathrm{m}$ ). The refinement of the austenite grain structure accelerates the bainitic transformation rate (Ref 31 ) and enhances ferrite formation due to the presence of more nucleation sites (Ref 43), thereby increasing mechanical properties of nanobainitic structure (Ref 31).

Based on experimental results, 9XC steel annealed at a lower temperature $\left(250{ }^{\circ} \mathrm{C}\right)$ has slightly lower dimensions of structure components (bainitic ferrite and austenite) and mostly fulfills the requirement of nanostructure (dimensions below $100 \mathrm{~nm})$. Sample annealed at a higher temperature $\left(300{ }^{\circ} \mathrm{C}\right)$ consists of a higher fraction of retained austenite with blocky morphology and slightly higher dimensions of bainitic ferrite laths compared to lower temperature of annealing $\left(250{ }^{\circ} \mathrm{C}\right)$. With the increase in blocky retained austenite, the microstructure becomes more coarse. The volume fraction of blocky austenite and thickness of filmy austenite increased with an 
increase in annealing temperature, which is also confirmed in research (Ref 44). This is well known that the ultimate tensile strength of nanobainitic steels depends on the thickness of bainitic laths (Ref 45$)$. The sample in which the nanostructured bainite was obtained is characterized by much higher hardness parameters (57 HRC) than the sample containing slightly coarser bainitic ferrite laths (50 HRC). Compared to other bearing nanobainitic steels, the obtained results had a comparable level of hardness (Table 7). It should be noted that the highest hardness was obtained for isothermal treatment performed below $250{ }^{\circ} \mathrm{C}$, which indicates that it is possible to increase the hardness of 9XC steel by reducing the temperature of isothermal heat treatment. On the other hand, the results obtained for the B-250-120 sample are satisfactory due to the relatively high hardness, relatively short isothermal treatment time and the obtained microstructure.

There are two types of retained austenite morphology: filmtype and blocky-type. Retained austenite with film-like morphology has higher stability compared with a blocky morphology due to higher carbon content and dislocation density (Ref $31,46)$. Filmy austenite is characterized by nanometric size of

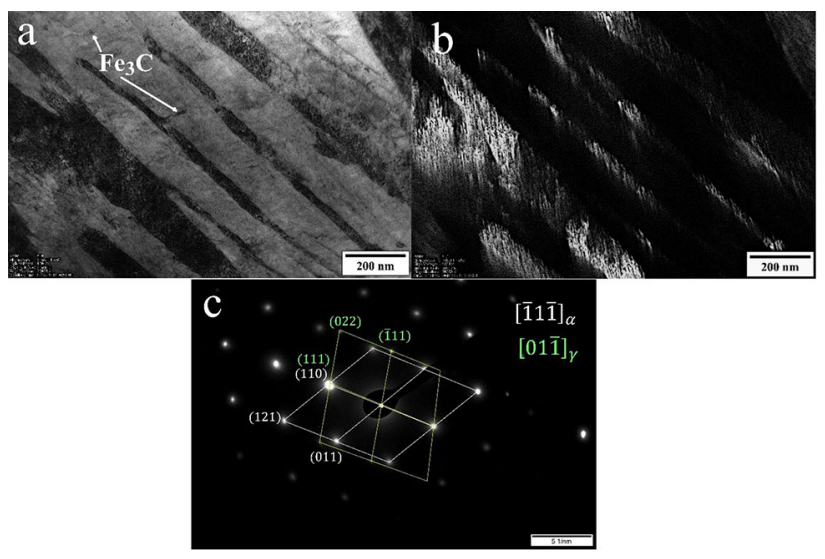

Fig. 8 (a) Bright-field image of the B-250-120 sample. (b) Dark field image obtained from reflection (111) from austenite (Fig. 8c). (c) Selected area diffraction pattern (SAED) of areas shown in Fig. 8a, along with the solution: $[\overline{1} 1 \overline{1}]_{\alpha} \|[01 \overline{1}]_{\gamma} .150 \mathrm{kV}$, TEM films width in the range of $15-100 \mathrm{~nm}$ (Ref 45). The less mechanical stable austenite will easier transform into martensite under stress (Ref 6, 19). Based on results, both types of retained austenite were identified in the microstructures. Sample annealed at lower temperatures had a lower content of austenite with blocky morphology. According to Zhang et al. (Ref 18), the film-like austenite between the ferrite prevents cracks from nucleating and extending. Therefore, the aim was also to minimize the content of unstable blocky austenite, thereby increasing mechanical properties such as hardness, impact toughness (Ref 47) of the nanobainitic steels. On the other hand, mechanically unstabilized retained austenite improves ductility and total elongation (Ref 48). Thus, a low fraction of blocky retained austenite in B-250-120 sample is preferred.

Obtaining nanostructured bainite in commercially available steel means the possibility of its applicability in industrial areas. However, further research should be focused on isothermal treatment in a low-temperature range (even below $250{ }^{\circ} \mathrm{C}$ ) to maximize the mechanical properties. The tested steel contains a relatively small amount of $\mathrm{Mn}$ and $\mathrm{Cr}$, which reduces hardenability but accelerates the bainitic transformation (Ref 16). After quenching in the designed cooling medium to isothermal temperature (liquid tin bath), bainitic structure without transformation diffusion-type products was obtained, which confirms the sufficient hardenability of this steel. The acceleration of bainitic transformation time also leads to lower costs, which is significant in the context of industrial application. This requires specifying the end time of the bainitic transformation. However, the precise determination of the end of the bainitic transformation is complex and subjective (Ref 49), which may cause contradictions and require further investigations. Besides, performing the treatment proposed in (Ref 50) could increase the hardness and mechanical and thermal stability of the microstructure. Thus, the tested steel can find its applications for bearings after improving heat treatment parameters and microstructure.

Table 7 The comparison of hardness for some nanobainitic bearing steels after the isothermal heat treatment in similar to the current research range of annealing temperatures

\begin{tabular}{|c|c|c|c|c|}
\hline Steel grade/chemical composition & Isothermal temp., ${ }^{\circ} \mathrm{C}$ & Hardness, HV1 & Hardness, HRC & References \\
\hline 9XC & 250 & $630 \pm 4$ & 57 & This research \\
\hline 9XC & 300 & $517 \pm 1$ & 50 & This research \\
\hline 100CrSiMn6-5-4 & 230 & 683 & 59 & Ref 50 \\
\hline 100CrSiMn6-5-4 & 280 & 554 & 53 & Ref 50 \\
\hline 100CrMnSi6-4 & 230 & 685 & 60 & Ref 50 \\
\hline 100CrMnSi6-4 & 280 & 597 & 55 & Ref 50 \\
\hline $100 \mathrm{Cr} 6$ & 230 & 716 & 61 & Ref 50 \\
\hline $100 \mathrm{Cr} 6$ & 280 & 629 & 57 & Ref 50 \\
\hline 100CrMnSi6-4 & 320 & 540 & 52 & Ref 22 \\
\hline 100CrSiMn6-5-4 & 220 & 712 & 61 & Ref 13 \\
\hline No. 6 (Table 1) & 200 & 632 & 57 & Ref 20 \\
\hline
\end{tabular}




\section{Conclusions}

In this research, the evaluation of the possibility to obtain nanostructured bainite in the commercial grade of steel $(9 \mathrm{XC}$ according to GOST) was determined. The following conclusions were formulated from the performed investigations::

1. The isothermal treatment carried out at low temperature $\left(250{ }^{\circ} \mathrm{C}\right.$ for $\left.120 \mathrm{~h}\right)$ allowed to achieve a nanometric scale of microstructure (bainitic ferrite in the range of 60$130 \mathrm{~nm}$, film-like austenite in the range of 30-50 nm). The austenite with film-like morphology dominated, while blocky austenite was found only locally.

2. At the higher temperature of the isothermal heat treatment $\left(300{ }^{\circ} \mathrm{C}\right.$ for $\left.72 \mathrm{~h}\right)$, the microstructure was coarser compared to the B-250-120 sample. The width of the bainitic ferrite laths was in the range of $120-150 \mathrm{~nm}$, and a film-like austenite in the range of $30-110 \mathrm{~nm}$. Besides, a high content of blocky austenite with relatively large dimensions (usually 1-3 $\mu \mathrm{m}$ ) was found.

3. The hardness of the B-250-120 sample (630.0 \pm 4.4 HV1, $57 \mathrm{HRC)}$ was more than $100 \mathrm{HV}$ higher than the hardness of the B-300-72 sample (517.3 $\pm 1.1 \mathrm{HV} 1,50$ HRC). The difference in hardness results from microstructural factors, such as microstructure refinement and the fraction of various austenite morphologies (blocky and film-like).

4. The obtained results are comparable to the nanobainitic bearing steels analyzed in other studies. The 9XC steel should be processed in a low-temperature range of isothermal heat treatment (even below $250{ }^{\circ} \mathrm{C}$ ) to maximize the mechanical properties required for bearing steels. However, this requires further research to determine the optimal heat treatment parameters.

\section{Open Access}

This article is licensed under a Creative Commons Attribution 4.0 International License, which permits use, sharing, adaptation, distribution and reproduction in any medium or format, as long as you give appropriate credit to the original author(s) and the source, provide a link to the Creative Commons licence, and indicate if changes were made. The images or other third party material in this article are included in the article's Creative Commons licence, unless indicated otherwise in a credit line to the material. If material is not included in the article's Creative Commons licence and your intended use is not permitted by statutory regulation or exceeds the permitted use, you will need to obtain permission directly from the copyright holder. To view a copy of this licence, visit http://creativecommons.org/licenses/by/4.0/.

\section{References}

1. H.K.D.H. Bhadeshia and D.V. Edmonds, Bainite in Silicon Steels: New Composition-Property Approach, Metals Sci., 1983, 17(9), p 420 425

2. J. Zhao, C.S. Hou, G. Zhao, T. Zhao, F.C. Zhang, and T.S. Wang, Microstructures and Mechanical Properties of Bearing Steels Modified for Preparing Nanostructured Bainite, J. Mater. Eng. Perform., 2016, 25(10), p 4249-4255
3. H.K.D.H. Bhadeshia, Nanostructured Bainite, Proc. R. Soc. A Math. Phys. Eng. Sci., 2010, 466(2113), p 3-18

4. T. Sourmail and V. Smanio, Low Temperature Kinetics of Bainite Formation in High Carbon Steels, Acta Mater., 2013, 61(7), p 26392648

5. P. Kirbiš, D. Feizpour, H. Kaker, and T. Irgolič, Annealing of a Nanostructured Bainitic Steel, Metallogr. Microstruct. Anal., 2020, h ttps://doi.org/10.1007/s13632-020-00612-x

6. Z. Yang and F. Zhang, Nanostructured Bainitic Bearing Steel, ISIJ Int., 2020, 60(1), p 18-30

7. F.G. Caballero, C. Garcia-Mateo, and M.K. Miller, Design of Novel Bainitic Steels: Moving from Ultrafine to Nanoscale Structures, JOM, 2014, 66(5), p 747-755

8. E. Kozeschnik and H.K.D.H. Bhadeshia, Influence of Silicon on Cementite Precipitation in Steels, Mater. Sci. Technol., 2008, 24(3), p 343-347

9. J. Zhao, B. Lv, F. Zhang, Z. Yang, L. Qian, C. Chen, and X. Long, Effects of austempering Temperature on Bainitic Microstructure and Mechanical Properties of a High-C High-Si Steel, Mater. Sci. Eng., A, 2019, 742, p 179-189

10. J. Zhao, T. Zhao, C.S. Hou, F.C. Zhang, and T.S. Wang, Improving Impact Toughness of High-C-Cr Bearing Steel by Si-Mo Alloying and Low-Temperature Austempering, Mater. Des., 2015, 86, p 215-220. h ttps://doi.org/10.1016/j.matdes.2015.07.055

11. F. Zhang and Z. Yang, Development of and Perspective on HighPerformance Nanostructured Bainitic Bearing Steel, Engineering, Chinese Academy of Engineering, 2019, 5(2), p 319-328. https://doi. org/10.1016/j.eng.2018.11.024

12. X. Long, F. Zhang, Z. Yang, and B. Lv, Study on Microstructures and Properties of Carbide-Free and Carbide-Bearing Bainitic Steels, Mater. Sci. Eng., A, 2018, 715(September 2017), p 10-16

13. P.V. Moghaddam, J. Hardell, E. Vuorinen, and B. Prakash, The Role of Retained Austenite in Dry Rolling/Sliding Wear of Nanostructured Carbide-Free Bainitic Steels, Wear, 2019, 428-429(November 2018), p 193-204. https://doi.org/10.1016/j.wear.2019.03.012

14. W. Solano-Alvarez, E.J. Pickering, M.J. Peet, K.L. Moore, J. Jaiswal, A. Bevan, and H.K.D.H. Bhadeshia, Soft Novel Form of WhiteEtching Matter and Ductile Failure of Carbide-Free Bainitic Steels Under Rolling Contact Stresses, Acta Mater., 2016, 121, p 215-226. h ttps://doi.org/10.1016/j.actamat.2016.09.012

15. M. St. Węglowski, J. Marcisz, and B. Garbarz, Technological Properties and Applications of High-Carbon Nanobainitic Steels, Biul. Inst. Spaw., 2018, 2018(3), p 29-43

16. C. Garcia-Mateo, T. Sourmail, F.G. Caballero, V. Smanio, M. Kuntz, C. Ziegler, A. Leiro, E. Vuorinen, R. Elvira, and T. Teeri, Nanostructured Steel Industrialisation: Plausible Reality, Mater. Sci. Technol. (United Kingdom), 2014, 30(9), p 1071-1078

17. F.C. Zhang, T.S. Wang, P. Zhang, C.L. Zheng, B. Lv, M. Zhang, and Y.Z. Zheng, A Novel Method for the Development of a LowTemperature Bainitic Microstructure in the Surface Layer of LowCarbon Steel, Scr. Mater., 2008, 59(3), p 294-296

18. F.C. Zhang, Z.G. Zhang, T.S.Wang Yan, and L.H. Qian, Wear Property of Low-Temperature Bainite in the Surface Layer of a Carburized Low Carbon Steel, Wear, 2011, 271(5-6), p 697-704. h ttps://doi.org/10.1016/j.wear.2010.12.025

19. H. Liu, J. Sun, T. Jiang, S. Guo, and Y. Liu, Improved Rolling Contact Fatigue Life for an Ultrahigh-Carbon Steel with Nanobainitic Microstructure, Scr. Mater., 2014, 90(1), p 17-20. https://doi.org/10. 1016/j.scriptamat.2014.07.006

20. W. Solano-Alvarez, E.J. Pickering, and H.K.D.H. Bhadeshia, Degradation of Nanostructured Bainitic Steel under Rolling Contact Fatigue, Mater. Sci. Eng., A, 2014, 617, p 156-164. https://doi.org/10.1016/j. msea.2014.08.071

21. C.M. Amey, H. Huang, and P.E.J. Rivera-Díaz-del-Castillo, Distortion in 100Cr6 and Nanostructured Bainite, Mater. Des., 2012, 35, p 66-71. https://doi.org/10.1016/j.matdes.2011.10.008

22. J. Dworecka, E. Jezierska, K. Rozniatowski, and W. Świątnicki, Characterization of Nanobainitic Structure Obtained in 100CrMnSi6-4 Steel after Industrial Heat Treatment, Arch. Metall. Mater., 2014, 59(4), p 1637-1640

23. C. Garcia-Mateo, F.G. Caballero, and H.K.D.H. Bhadeshia, Bainite At a Low Temperature in a Steel Designed for a Specific Structural Application, ISIJ Int., 2003, 43(8), p 1238-1243 
24. F.G. Caballero and H.K.D.H. Bhadeshia, Very Strong Bainite, Curr Opin. Solid State Mater. Sci., 2004, 8(3-4), p 251-257

25. M. Shah and S. Das Bakshi, Three-Body Abrasive Wear of CarbideFree Bainite, Martensite and Bainite-Martensite Structure of Similar Hardness, Wear, 2018, 402-403(February), p 207-215. https://doi.org/ 10.1016/j.wear.2018.02.020

26. G. Miyamoto, H. Usuki, Z.D. Li, and T. Furuhara, Effects of Mn, Si and $\mathrm{Cr}$ Addition on Reverse Transformation at $1073 \mathrm{~K}$ from Spheroidized Cementite Structure in Fe-0.6 Mass\% C Alloy, Acta Mater., 2010, 58(13), p 4492-4502. https://doi.org/10.1016/j.actamat. 2010.04.045

27. G. Miyamoto, J.C. Oh, K. Hono, T. Furuhara, and T. Maki, Effect of Partitioning of $\mathrm{Mn}$ and $\mathrm{Si}$ on the Growth Kinetics of Cementite in Tempered Fe-06 Mass\% C Martensite, Acta Mater., 2007, 55(15), p 5027-5038

28. B. Kim, C. Celada, D. San Martín, T. Sourmail, and P.E.J. RiveraDíaz-Del-Castillo, The Effect of Silicon on the Nanoprecipitation of Cementite, Acta Mater., 2013, 61(18), p 6983-6992

29. K. Zhu, H. Shi, H. Chen, and C. Jung, Effect of Al on Martensite Tempering: Comparison with Si, J. Mater. Sci., 2018, 53(9), p 69516967. https://doi.org/10.1007/s10853-018-2037-6

30. A. Królicka, K. Radwański, A. Ambroziak, and A. Żak, Analysis of Grain Growth and Morphology of Bainite in Medium-Carbon Spring Steel, Mater. Sci. Eng. A, 2019. https://doi.org/10.1016/j.msea.2019. 138446

31. T. Jiang, H. Liu, J. Sun, S. Guo, and Y. Liu, Effect of Austenite Grain Size on Transformation of Nanobainite and Its Mechanical Properties, Mater. Sci. Eng., A, 2016, 666, p 207-213. https://doi.org/10.1016/j. msea.2016.04.041

32. S.J. Lee, J.S. Park, and Y.K. Lee, Effect of Austenite Grain Size on the Transformation Kinetics of Upper and Lower Bainite in a Low-Alloy Steel, Scr. Mater., 2008, 59(1), p 87-90

33. K. Singh, A. Kumar, and A. Singh, Effect of Prior Austenite Grain Size on the Morphology of Nano-Bainitic Steels, Metall. Mater. Trans. A Phys. Metall. Mater. Sci., 2018, 49(4), p 1348-1354. https://doi.org/10. 1007/s11661-018-4492-8

34. E.C. Bain, The Nature of Martensite, Trans. AIME Steel, 1924, 79, p 25-35

35. G. Sachs, G. Kurdjumov, Over the Mechanisms of Steel Hardening, $Z$. Phys., 1930, 64, p 325-343

36. A.B. Greninger and A.R. Troiano, The Mechanism of Martensite Formation, JOM, 1949, 185(September), p 590-598

37. Z. Nishiyama, X-Ray Investigation the Mechanism of Transformation from Face-Centred-Cubic Lattice to Body-Centred Cubic, Sci. Rep. Res. Inst., Tohoku Univ., 1934, 23, p 638

38. S.J. Wang, H. Wang, K. Du, W. Zhang, M.L. Sui, and S.X. Mao, Deformation-Induced Structural Transition in Body-Centred Cubic Molybdenum, Nat. Commun., 2014, 5, p 3433

39. H. Beladi, V. Tari, I.B. Timokhina, P. Cizek, G.S. Rohrer, A.D. Rollett, and P.D. Hodgson, On the Crystallographic Characteristics of Nanobainitic Steel, Acta Mater., 2017, 127, p 426-437. https://doi. org/10.1016/j.actamat.2017.01.058

40. Y. Guo, C. Yao, K. Feng, Z. Li, P.K. Chu, and Y. Wu, Effect of Isothermal Temperature on Growth Behavior of Nanostructured
Bainite in Laser Cladded Coatings, Materials (Basel), 2017, 10(7), p $1-16$

41. Z. Guo, C.S. Lee, and J.W. Morris, On Coherent Transformations in Steel, Acta Mater., 2004, 52(19), p 5511-5518

42. T. Furuhara, H. Kawata, S. Morito, G. Miyamoto, and T. Maki, Variant Selection in Grain Boundary Nucleation of Upper Bainite, Metall. Mater. Trans. A Phys. Metall. Mater. Sci., 2008, 39A(5), p 1003-1013

43. H. Luo, L. Zhao, S.O. Kruijver, J. Sietsma, and S. Van der Zwaag, Effect of Intercritical Deformation on Bainite Formation in AlContaining TRIP Steel, ISIJ Int., 2003, 43(8), p 1219-1227

44. A. Kumar and A. Singh, Toughness Dependence of Nano-Bainite on Phase Fraction and Morphology, Mater. Sci. Eng., A, 2018, 729(March), p 439-443. https://doi.org/10.1016/j.msea.2018.05.106

45. I.B. Timokhina, H. Beladi, X.Y. Xiong, Y. Adachi, and P.D. Hodgson, Nanoscale Microstructural Characterization of a Nanobainitic Steel, Acta Mater., 2011, 59(14), p 5511-5522. https://doi.org/10.1016/j.acta mat.2011.05.024

46. R. Ding, D. Tang, and A. Zhao, A Novel Design to Enhance the Amount of Retained Austenite and Mechanical Properties in LowAlloyed Steel, Scr. Mater., 2014, 88, p 21-24. https://doi.org/10.1016/ j.scriptamat.2014.06.014

47. B. Avishan, S. Yazdani, and S. Hossein Nedjad, Toughness Variations in Nanostructured Bainitic Steels, Mater. Sci. Eng., A, 2012, 548, p 106-111. https://doi.org/10.1016/j.msea.2012.03.098

48. F.G. Caballero and C. Garcia-Mateo, The Role of Retained Austenite on Tensile Properties of Steels with Bainitic Microstructures, Mater. Trans., 2005, 46(8), p 1839-1846

49. M.A. Santajuana, A. Eres-Castellanos, V. Ruiz-Jimenez, S. Allain, G. Geandier, F.G. Caballero, and C. Garcia-Mateo, Quantitative Assessment of the Time to End Bainitic Transformation, Metals (Basel), 2019, 9(9), p 7-17

50. T. Sourmail, F.G. Caballero, F. Moudian, D. De Castro, and M. Benito, High Hardness and Retained Austenite Stability in Si-Bearing Hypereutectoid Steel through New Heat Treatment Design Principles, Mater. Des., 2018, 142, p 279-287. https://doi.org/10.1016/j.matdes.2018.01. 035

51. C. Capdevila, F.G. Caballero, and C.G. de Andrés, Determination of Martensite-Start Temperature in Steels: Bayesian Neural Network Model, ISIJ Int., 2002, 42(8), p 894-902

52. R.A. Grange and A.H.M. Stewart, The Temperature Range of Martensite Formation, Trans. AIME, 1946, 167, p 467-490

53. S. Kang, S. Yoon, and S.J. Lee, Prediction of Bainite Start Temperature in Alloy Steels with Different Grain Sizes, ISIJ Int., 2014, 54(4), p 997-999

54. S.M.C. Van Bohemen, Bainite and Martensite Start Temperature Calculated with Exponential Carbon Dependence, Mater. Sci. Technol., 2012, 28(4), p 487-495

Publisher's Note Springer Nature remains neutral with regard to jurisdictional claims in published maps and institutional affiliations. 